\title{
Cucumber Seed Oil
}

National Cancer Institute

\section{Source}

National Cancer Institute. Cucumber Seed Oil. NCI Thesaurus. Code C107295.

The oil extracted from the seeds of Cucumis sativus. Cucumber seed oil is used primarily in skincare preparations. 